\title{
Pengaruh Kualitas Produk terhadap Pemilihan Vendor di PT. Hitachi Power Systems Indonesia
}

Khanifan Budhy Luhur ${ }^{1}$, Sutandi ${ }^{2}$

${ }^{1,2}$ Institut Ilmu Sosial dan Manaemen STIAMI, Jakarta, Indonesia

Email: khanifanbudhy@gmail.com¹, sutandikindi@gmail.com²

\begin{tabular}{|c|c|}
\hline \multicolumn{2}{|c|}{ ARTICLE INFO } \\
\hline \multicolumn{2}{|c|}{ Article history } \\
\hline Received & $2020-10-20$ \\
\hline Revised & $2020-10-25$ \\
\hline Accepted & $2020-10-31$ \\
\hline
\end{tabular}

\begin{abstract}
This research was conducted at PT. Hitachi Power Systems Indonesia. The purpose of this research is to determine the results of data analysis of the effect of Product Quality on Vendor Selection at PT. Hitachi Power Systems Indonesia by distributing questionnaires of 40 respondents. The research methodology used is quantitative descriptive research method. The analysis results show the value of t-count> t-table (5.478> 1.685). This means that Ho is rejected and $\mathrm{HI}$ is accepted, or there is an influence between Product Quality and Vendor Selection. And from the results of calculations using SPSS version 20, the coefficient of determination (R2) shows the value of $R$ Square $=0.441$.This means that the Product Quality variable $(X)$ can explain or explain the Vendor Selection $(Y)$ of $44.1 \%$, the remaining $55.9 \%$ ( from the calculation of $100 \%$ $44.1 \%)$ influenced by other variables not included in the model or equation in this study.The analysis results show the value of $t$-count $>t$-table (5.478> 1.685). This means that Ho is rejected and $H 1$ is accepted, or there is an influence between Product Quality and Vendor Selection.
\end{abstract}

\section{A. PENDAHULUAN}

Perusahaan Hitachi Power Systems Indonesia merupakan salah satu usaha pembuatan dan penjualan SF6 Gas Circuit Breaker berkapasitas tinggi (GCB) dan High Voltage SF6 Gas Insulated Switchgears (GIS) untuk sistem tranmisi dan distribusi. Produk-produk ini dipasok ke Negara-negara Asia dan termasuk layanan purna jual (instalasi dan commissioning). Dalam jaman sekarang ini setiap perusahaan bergerak di berbagai bidang harus mampu bersaing dalam menjalankan usahanya, oleh karena itu perusahaan harus meningkatkan kualitas produk yang dihasilkannya dan juga aktivitas kerja dari perusahaan untuk dapat mencapai tujuan usahanya. Salah satu aktivitas di PT. Hitachi Power Systems Indonesia yaitu logistik, dimana di dalam kegiatan logistik tersebut terdapat banyak kegiatan. Misal, dalam Pemilihan Vendor tentunya akan dipengaruhi oleh kualitas produknya.

Dalam kegiatan logistiknya, PT. Hitachi Power Systems Indonesia di bagi berbagai bagian. Pertama Departemen PPIC, didalamnya ada Material Control, Planning, Inventory, Vendor Progres Control (VPC), Distribusi, Warehouse dan Dokumen. Kedua Departemen Procurement, didalamnya ada Pengadaan, Ekspor-Impor, Pembelian dan Moda Transportasi. Ketiga Departemen Shipping, di dalamnya ada Preparetion, Distribution, Dokumentasi, Impor Part dan Local Part. Semua departemen tersebut harus melaksanakan fungsi masing-masing dengan baik, teratur, tepat waktu, perhitungan yang tepat dan berkesinambungan agar kualitas produk yang dihasilkan sesuai dengan keinginan pelanggan sehingga meningkatkan kepuasan pelanggan dan kepercayaan pelanggan terhadap kinerja dari perusahaan, dan hubungan antar pelanggan dengan perusahaan akan terjalin dengan baik.

Vendor dalam arti harfiahnya, vendor adalah penjual. Namun, vendor memiliki artian yang lebih spesifik yakni pihak ketiga dalam supply chain istilah dalam industri yang menghubungkan produk dari produsen untuk sampai ke customer yang menjual barang kepada perusahaan yang dijual kembaliatau dipergunakan oleh user dari perusahaan tersebut. Dalam hal ini, vendor dapat pula disebut supplier dari produk atau jasa. Kegiatan pengadaan adalah usaha untuk mendapatkan barang berupa material dan 
peralatan dan atau jasa dari pihak luar untuk proyek. Adapun proses pengadaan barang terdiri dari beberapa aktivitas. Salah satunya adalah pengelolaan vendor. Pengelolaan vendor adalah aktivitas yang dilakukan oleh perusahaan untuk memastikan vendor mampu memenuhi target pengadaan barang sehingga kegiatan bisnis yang berkaitan dengan vendor dapat lebih cermat untuk mendukung jalannya kegiatan bisnis perusahaan dan memper-erat hubungan bisnis dengan vendor. Vendor yang baik yaitu vendor yang mempunyai standar kriteria yang telah ditetapkan. Penetapan vendor merupakan bagian dari aktivitas pengelolaan vendor.

Saat ini pengelolaan vendor di PT Hitachi Power Systems Indonesia khususnya dalam menetapkan vendor perusahaan belum memiliki ketentuan yang jelas sehingga tidak dapat diukur waktunya di PT Hitachi Power Systems Indonesia data vendor belum terkelola dengan baik dan belum juga memperhatikan hal-hal secara spesifik seperti kriteria-kriteria yang harus dipenuhi, sehingga tidak dapat meminimalisir kesalahan dan keterlambatan pengiriman yang mengakibatkan proses-proses yang terkait terhambat. Permasalahan yang muncul yaitu dalam produksinya perusahaan masih menghasilkan produk cacat terutama produk yang dikerjakan oleh vendor. Langkah yang harus dilakukan yaitu melakukan analisis pemilihan vendor yang mempunyai kualitas produk baik, untuk menentukan kualitas produk saat ini atau baseline kinerja yang dicapai perusahaan sebagai tahap awal dalam meningkatkan kualitas produk. Dalam penelitan ini yang menjadi fokus penelitian yaitu pada kualitas produk yang dihasilkan oleh vendor PT Hitachi Power

Systems Indonesia karena produk vendor menjadi produk pendukung untuk kelancaran projectproject yang diterima perusahaan.

\section{Identifikasi Masalah}

Berdasarkan latar belakang masalah yang telah di uraikan pada bagian terdahulu, maka penulis hanya meneliti proses Pengaruh Kualitas Produk (X) terhadap Pemilihan Vendor (Y) pada PT. Hitachi Power Systems Indonesia.

\section{Tujuan Penelitian}

Berdasarkan rumusan masalah yang ada maka tujuan penelitian ini adalah untuk mengetahui pengaruh kualitas produk terhadap pemilihan vendor.

\section{B. KAJIAN LITERATUR}

\section{Kualitas Produk}

Menurut Kotler (2005:49), kualitas adalah keseluruhan ciri serta dari suatu produk atau pelayanan pada kemampuan untuk memuaskan kebutuhan yang dinyatakan/tersirat. Melalui pengertian dan teori ini dapat diketahui bahwa suatu barang atau jasa akan di nilai bermutu apabila dapat memenuhi ekspektasi konsumen akan nilai produk yang diberikan kepada konsumen tersebut. Artinya, mutu atau kualitas merupakan salah satu faktor yang menentukan penilaian kepuasan konsumen.

Menurut Lupioadi (2001:158) Kualitas itu ketika konsumen akan merasa puas apabila hasil evaluasi mereka menunjukkan bahwa produk yang mereka gunakan berkualitas.

Menurut Orville, Larreche dan Boyd (2005:422), apabila perusahaan ingin mempertahankan keungulan kompetitifnya dalam pasar, perusahaan harus mengerti aspek apa saja yang digunakan oleh konsumen untuk membedakan produk yang di jual perusahaan tersebut dengan produk pesaing.

\section{Pemilihan Vendor}

Pemilihan vendor pada perusahaan sangat penting, hal ini dikarenakan vendormemegang peranan penting dalam ketersedian bahan baku. Bahan baku dibutuhkan agar perusahaan dapat melakukan aktivitas produksinya dengan lancar. Dengan mengutamakan kualitas maka PT. Hitachi 
Power Systems Indonesia dapat meraih keunggulan bersaing dengan strategi quick respon dan low cost. Secara tidak langsung dengan pemilihan vendor yang tepat dapat memberikan keuntungan bagi perusahaan tidak hanya dari kegiatan produksi tetapi dalam segi pelayanan dan penjualan yang berkaitan erat dengan meningkatkan kepuasan pelanggan. Pemilihan vendor biasanya mempertimbangkan biasanya kualitas dari produk, service/pelayanan dan ketepatan waktu pengiriman adalah hal yang penting, meskipun ada beberapa faktor lain yang harus dipertimbangkan. Faktor utama yang dipertimbangkan oleh suatu perusahaan ketika memilih vendor adalah : (William J Stevenson, 2002: 701)

a. Harga: Faktor ini biasanya merupakan faktor utama, apakah terdapat penawaran diskon, meskipun hal itu kadangkala tidak menjadi hal yang paling penting.

b. Kualitas: Suatu perusahaan mungkin akan membelanjakan lebih besar biayanya untuk mendapatkan kualitas barang yang baik.

c. Pelayanan: Pelayanan yang khusus kadang kala dapat menjadi hal yang penting dalam pemilihan vendor. Penggantian atas barang yang rusak, petunjuk cara penggunaan, perbaikan peralatan dan pelayanan yang sejenis, dapat menjadi kunci dalam pemilihan satu vendor daripada yang lain.

d. Lokasi: Lokasi vendor dapat mempunyai pengaruh pada waktu pengiriman, biaya transportasi,

e. waktu respon saat ada order/pesanan yang mendadak atau pelayanan yang bersifat darurat. Pembelian pada daerah setempat/lokal dapat menumbuhkan goodwill (pengaruh baik) dalam suatu hubungan serta dapat membantu perekonomian daerah sekitar.

f. Kebijakan persediaan vendor: Jika vendor dapat memelihara kebijakan persediaannya dan menjaga spare part yang dimilikinya, hal ini dapat membantu dalam kasus kebutuhan bahan baku yang mendadak.

g. Fleksibilitas: Niat yang baik dan kemampuan vendor dalam merespon perubahan permintaan dan memenuhi perubahan desain pesanan dapat menjadi faktor yang penting dalam pemilihan vendor.

\section{METODE PENELITIAN}

\section{Pendekatan dan Jenis Penilitian}

Metode penelitian yang digunakan dalam penelitian ini adalah metode deskriptif dengan pendekatan penelitian kuantitatif. Metode deskriptif adalah metode yang meneliti status sekelompok manusia, objek, kondisi tertentu, ataupun suatu kilas peristiwa masa sekarang. Tujuannya adalah untuk membuat deskripsi, gambaran, atau lukisan secara sistematis, faktual, dan akurat mengenai fakta, sifat hubungan antara fenomena yang diselidiki.

Menurut Sekaran (2011: 115), variabel adalah apapun yang dapat membedakan atau membawa variasi dalam nilai. Variabel penelitian merupakan suatu atribut dari kelompok objek yang diteliti, mempunyai variasi antara satu dan yang lainnya dalam kelompok tersebut. Dalam penelitian ini variabel penelitian adalah kriteria pemilihan vendordengan subvariabel antara lain: Kualitas.

\section{Teknik Pengumpulan Data}

Pengumpulan data dalam penelitian ini diantaranya yaitu sebagai berikut:

1) Kuesioner

Kuesioner adalah sejumlah pertanyaan tertulis yang digunakan untuk memperoleh informasi dari responden dalam arti laporan tentang pribadinya, atau hal-hal yang ia ketahui (Arikunto, 2002). Kelebihan menggunakan kuesioner adalah dalam waktu yang relatif singkat dapat memperoleh data yang banyak, tenaga yang diperlukan sedikit dan responden dapat menjawab dengan bebas tanpa pengaruh orang lain. Sedangkan kelemahan kuesioner adalah angket bersifat kaku karena pertanyaan yang telah ditentukan dan responden tidak memberi jawaban yang sesuai dengan keadaan dirinya hanya sekedar membaca kemudian menulis jawabannya.

2) Studi Dokumentasi

Dokumen adalah segala benda yang berbentuk barang, gambar, ataupun tulisan sebagi bukti dan dapat memberikan keterangan yang penting dan absah. Dokumentasi adalah kumpulan dari 
dokumen-dokumen yang dapat memberikan keterangan atau bukti yang berkaitan dengan proses pengumpulan dan pengelolaan dokumen secara sistematis serta menyebarluaskan kepada pemakai informasi tersebut. Peneliti memperoleh data dan dokumen-dokumen tertulis.Penulis membaca dan mempelajari berbagai tulisan dari buku-buku, jurnal-jurnal, dan internet yang berkaitan dan mendukung kebanaran dan keabsahan dari hasil yang diperoleh dari penelitian ini.

\section{Populasi dan Sampel}

Populasi yang menjadi sasaran adalah karyawan dari PT. Hitachi Power Systems Indonesia untuk mengisi kuesioner peneliti dan ada 40 karyawan terdiri dari 36 karyawan laki laki dan 6 karyawan perempuan PT. Hitachi Power Systems Indonesia yang akan mengisi kuesioner dari peneliti. Maka dari itu apa yang telah dipelajari dari sampel itu sendiri dapat memiliki kesimpulan yang akan di berlakukan terhadap populasi, karyawan yang di berikan kuesioner adalah karyawan yang sudah memiliki pengalaman langsung dan berhubungan dengan pemilihan vendor pada PT. Hitachi Power Systems Indonesia dari populasi 400. Maka peneliti sudah mempelajari dan menyimpulkan sampel yang akan di ambil sebanyak 40 Responden.

\section{Teknik Analisis Data}

1. Uji Validitas dan Realibilitas

a) Uji Validitas

Menurut Ghozali (2009), menyatakan bahwa uji validitas digunakan untuk mengukur sah atau valid tidaknya suatu kuesioner. Suatu kuesioner dinyatakan valid jika pertanyaan pada kuesioner mampu mengungkapkan sesuatu yang akan diukur oleh kuesioner tersebut.

Menurut Kusaeri (2012:75), validitas merupakan ketepatan (appropriateness), kebermaknaan (meaningfull), dan kemanfaatan (usefulness) dari sebuah kesimpulan yang didapatkan dari intepretasi skortes. Uji validitas dalam penelitian ini digunakan analisis item yaitu mengkorelasikan skor tiap butir dengan skor total yang merupakan jumlah daritiap skor butir. Jika ada item yang tidak memenuhi syarat maka item tersebut tidak akan diteliti lebih lanjut. Syarat tersebut menurut Sugiyono (2010:134) yang harus dipenuhi yaitu harus memiliki kriteria sebagai berikut:

1) Jika $r \geq 0,30$, maka item-item dari kuesioner adalah valid

2) Jika $r \leq 0,30$, maka item-item dari kuesioner adalah tidak valid

Uji validitas instrument dapat menggunakan rumus korelasi. Rumus korelasi berdasarkan

Pearson Product Moment menurut Sugiyono (2010:183) adalah sebagai berikut:

$$
r_{X Y}=\frac{N \sum X Y-\left(\sum X\right)\left(\sum Y\right)}{N \sum X^{2}-\left(\sum X^{2}\right) \cdot\left(N \sum Y^{2}-\left(\sum Y^{2}\right)\right.}
$$

Keterangan :

$\mathrm{N}=$ Banyaknya sampel

$\sum_{i}=$ Jumlah skor keseluruhan untuk item pertanyaan variabelX

$\sum=$ Jumlah skor keseluruhan untuk item pertanyaan variabelY

Dalam penelitian ini uji validitas data menggunakan rumus korelasi product moment. Sesuai dengan hasil perhitungan dengan bantuan program komputer SPSS for Windows Versi 20.

b) Uji Realibilitas

Menurut Riyadi 2000 dalaml Amri (2009:35), uji reabilitas dilakukan untuk mengetahui seberapa jauh hasil pengukuran tetap konsisten apabila dilakukan pengukuran dua kali atau lebih terhadap gejala yang sama dengan menggunaka alat pengukuran yang sama. 
Uji reliabilitas adalah tingkat kestabilan atau konsistensi suatu alat ukur dalam mengukur suatu gejala atau kejadian.Semakin tinggi reliabilitas suatu alat pengukur, semakin stabil pula alat pengukur tersebut untuk mengukur suatu gejala dan sebaliknya jika reliabilitas tersebut rendah maka alat tersebut tidak stabil dalam mengukur suatu gejala. Uji reliabilitas dimaksudkan untuk mengukur sampai sejauh mana derajat ketepatan, ketelitian atau keakuratan yang ditunjukkan oleh instrumen pengukuran(Umar,2004).

Uji reliabilitas dilakukan dengan metode internal consistency.Internal consistency diukur dengan menggunakan koefisien Cronbach Alpha. Ketentuan pengambilan keputusan yang digunakan adalah:

1) Jika nilai Alpha $>0,5$ maka variabel tersebut berstatusreliabel.

2) Jika nilai Alpha $<0,5$ maka variabel tersebut berstatus tidak reliabel.

Berdasarkan hasil uji reliabilitas dengan software pengolah data IBM SPSS versi 20, maka diketahui: Uji Reliabilitas Kualitas Produk dan Pemilihan Vendor.

Tabel 1. Uji Reliabilitas

\begin{tabular}{|c|c|c|c|c|}
\hline No. & Variabel & Ketentuan & Croanbach alpha & Keterangan \\
\hline $\mathbf{1}$ & Kualitas Produk $(\mathrm{X})$ & 0,5 & 0,766 & Reliabel \\
\hline $\mathbf{2}$ & Pemilihan Vendor $(\mathrm{Y})$ & 0,5 & 0,780 & Reliabel \\
\hline
\end{tabular}

Hasil penghitungan tabel di atas menunjukkan nilai Koefisien Croanbach alpha variabel kualitas produk $(\mathrm{X})$ adalah 0,766. Dan nilai Koefisien Croanbach alpha variabel pemilihan vendor (Y) adalah 0,780. Nilai tersebut lebih besar dari 0,5 maka dapat dinyatakan bahwa kedua variabel penelitian reliabel.

\section{HASIL DAN PEMBAHASAN}

\section{Uji Regresi Linier Sederhana}

Berdasarkan hipotesis yang diajukan dalam penelitian ini, untuk melihat pengaruh hubungan antar variabel, maka analisis data menggunakan analisis regresi linier sederhana. Sebelum data tersebut dianalisis dengan regresi linier sederhana, harus diuji linieritas terlebih dahulu. Selain itu, data juga harus terbebas dari asumsi klasik meliputi multikolinieritas, heteroskedastisitas dan autokorelasi.

Tabel 2. Hasil Uji Regresi Linier Sederhana

\begin{tabular}{|l|r|r|r|r|r|}
\hline \multicolumn{7}{|c|}{ Coefficients $^{\mathbf{a}}$} \\
\hline \multirow{2}{*}{ Model } & \multicolumn{2}{|c|}{$\begin{array}{c}\text { Unstandardized } \\
\text { Coefficients }\end{array}$} & $\begin{array}{c}\text { Standardized } \\
\text { Coefficients }\end{array}$ & $\mathrm{t}$ & Sig. \\
\cline { 2 - 6 } & $\mathrm{B}$ & Std. Error & Beta & & \\
\hline Constant) & 6.852 & 6.142 & & 1.116 & .272 \\
\hline Kualitas Produk & .833 & .152 & .664 & 5.478 & .000 \\
\hline \multicolumn{7}{|l|}{ a. Dependent Variable: Pemilihan Vendor } \\
\hline
\end{tabular}

Dari Tabel di atas (kolom B) diperoleh persamaan regresilinier berganda :

$$
\mathrm{Y}=\mathbf{5 , 4 3 3 + 0 , 1 7 1 X}
$$


Keterangan:

$\mathrm{Y}=$ Pemilihan Vendor

$\mathrm{X}=$ Kualitas Produk

Nilai a $=6,852$ adalah konstanta. Artinya apabila variabel Kualitas Produk (X) sama dengan nol, maka Pemilihan Vendor (Y) sebesar 6,852. Diketahui besarnya koefisien regresi Kualitas Produk (X) diperoleh 0,833 bernilai positif. Hasil tersebut menunjukkan bahwa setiap terjadi peningkatan Kualitas Produk (X) sebesar satu satuan maka akan diikuti oleh peningkatan Pemilihan Vendor (Y) sebesar 0,833 satuan atau sebaliknya apa bila terjadi penurunan Kualitas Produk (X) sebesar satu satuan maka akan diikuti oleh penurunan Pemilihan Vendor (Y) sebesar 0,833 satuan.

2. Hasil Uji Normalitas

Tabel 3. Hasil Uji Normalitas K-S

\begin{tabular}{|l|l|r|}
\hline \multicolumn{2}{|c|}{ One-Sample Kolmogorov-Smirnov Test } \\
\hline \multicolumn{2}{|l|}{} & $\begin{array}{c}\text { Unstandardized } \\
\text { Residual }\end{array}$ \\
\hline $\mathrm{N}$ & Mean & $0 \mathrm{E}-7$ \\
\hline \multirow{3}{*}{ Normal Parameters ${ }^{\mathrm{a}, \mathrm{b}}$} & Std. Deviation & .180 \\
\hline \multirow{3}{*}{ Most Extreme Differences } & Absolute & .137 \\
\cline { 2 - 4 } & Positive & -.180 \\
\cline { 2 - 3 } & Negative & 1.137 \\
\hline Kolmogorov-Smirnov Z & & .151 \\
\hline Asymp. Sig. (2-tailed) & & 4.12973022 \\
\hline
\end{tabular}

a. Test distribution is Normal.

b. Calculated from data.

Berdasarkan uji normalitas K-S/ Kolmogorov-Smirnov di atas, terlihat signifikansi dua arah X terhadap Y adalah 0,151 . Nilai signifikan variabel yang diuji tersebut $>0,05$, maka dapat disimpulkan data pada normal memiliki data yang sama dengan distribusi normal.

c. Uji Hipotesis

Tabel 3. Hasil Penghitungan Koefisien Korelasi

\begin{tabular}{|c|c|c|c|}
\hline \multicolumn{4}{|c|}{$\begin{array}{c}\text { Tabel Hasil Penghitungan Koefisien Korelasi } \\
\text { Correlations }\end{array}$} \\
\hline & & Kualitas Produk & Pemilihan Vendor \\
\hline \multirow{3}{*}{ Kualitas Produk } & Pearson Correlation & 1 & $.664^{* * *}$ \\
\hline & Sig. (2-tailed) & & .000 \\
\hline & $\mathrm{N}$ & 40 & 40 \\
\hline \multirow{3}{*}{ Pemilihan Vendor } & Pearson Correlation & $.664^{* * *}$ & 1 \\
\hline & Sig. (2-tailed) & .000 & \\
\hline & $\mathrm{N}$ & 40 & 40 \\
\hline
\end{tabular}


Hasil penghitungan tabel di atas menunjukkan nilai Koefisien Korelasi (R) sebesar 0,664. Nilai tersebut menunjukkan bahwa pengaruh variabel Kualitas Produk terhadap Pemilihan Vendor adalah kuat.

Menurut Sarwono (2006), ketentuan koefisien korelasi (r) dapat diketahui melalui indikator sebagai berikut :

0 : Tidak ada korelasi antara dua variabel

$>0-0,25$ : Korelasi sangat lemah

$>0,25-0,5$ : Korelasi cukup

$>0,5-0,75$ : Korelasi kuat

$>0,75-0,99$ : Korelasi sangat kuat

1: Korelasi sempurna

d. Koefisien Determinasi

Tabel 3. Hasil Penghitungan Koefisien Determinasi

\begin{tabular}{l|l|l|r|r|r|}
\hline Model & $\mathrm{R}$ & R Square & Adjusted R Square & $\begin{array}{c}\text { Std. Error of the } \\
\text { Estimate }\end{array}$ \\
\hline 1 & & $.664^{\mathrm{a}}$ & .441 & & 4.184 \\
\hline
\end{tabular}

b. Dependent Variable: Pemilihan Vendor

Sedangkan koefisien determinasi $\left(R^{2}\right)$ menunjukkan nilai $R$ Square $=0,441$ Artinya variabel Kualitas Produk (X) dapat menerangkan atau menjelaskan Pemilihan Vendor (Y) sebesar $44,1 \%$, sisanya sebesar 55,9 \% (dari penghitungan 100\%-44,1\%) dipengaruhi oleh variabel lain yang tidak termasuk dalam model atau persamaan pada penelitian ini.

e. Hasil Uji T

Tabel Uji Hipotesis T

\begin{tabular}{|c|c|c|c|c|c|}
\hline \multicolumn{6}{|c|}{ Coefficients $^{\mathrm{a}}$} \\
\hline \multirow[t]{2}{*}{ Model } & \multicolumn{2}{|c|}{$\begin{array}{c}\text { Unstandardized } \\
\text { Coefficients } \\
\end{array}$} & $\begin{array}{l}\text { Standardized } \\
\text { Coefficients }\end{array}$ & $\mathrm{t}$ & Sig. \\
\hline & $\mathrm{B}$ & Std. Error & Beta & & \\
\hline (Constant) & 6.852 & 6.142 & & 1.116 & .272 \\
\hline $\begin{array}{l}\text { Kualitas } \\
\text { Produk }\end{array}$ & .833 & .152 & .664 & 5.478 & .0 \\
\hline
\end{tabular}

Berdasarkan Tabel 4.35, menunjukkan variabel Kualitas Produk (X) mempunyai nilai t- Hitung sebesar 5,478. Nilai t-Tabel yang merupakan standar untuk mengambil keputusan pada hipotesis dicari dengan menentukan $\mathrm{df}$. Nilai $\mathrm{df}=\mathrm{n}-\mathrm{k}$, $\mathrm{n}$ adalah jumlah responden dan $\mathrm{k}$ adalah jumlah semua variabel dalam penelitian ini $(\mathrm{df}=\mathrm{n}-\mathrm{k}=40-2=38)$, diperoleh nilai t-Tabel pada tingkat signifikansi 0,05 yaitu sebesar 1,685. Pada penelitian ini terdapat hipotesis:

$\mathrm{H}_{0}=$ Tidak terdapat pengaruh antara Kualitas Produk terhadap Pemilihan Vendor.

$\mathrm{H}_{1}=$ Terdapat pengaruh antara Kualitas Produk terhadap Pemilihan Vendor. 
Hasil analisis menunjukkan nilai t-Hitung > t-Tabel $(5,478>1,685)$. Hal ini berarti $\mathrm{H}_{\mathrm{o}}$ olak dan $\mathrm{H}_{1}$ diterima atau terdapat pengaruh antara Kualitas Produk terhadap Pemilihan Vendor.

\section{Pembahasan}

Berdasarkan dengan judul yang akan peneliti teliti dan hasil penelitian di atas, maka peneliti melakukan pembuktian untuk mengetahui besar pengaruh variabel kualitas produk terhadap pemilihan vendor. Berdasarkan Rekapitulasi Kualitas Produk, pada variabel kualitas produk didapat hasil rata-rata sebesar 4,0175 untuk hal ini dinilai baik.

Dari hal tersebut menunjukan bahwa pengaruh kualitas produk terhadap pemilihan vendor berpengaruh dikarenakan tidak lebih dari 50\% indikator yang berada dibawah rata-rata. Selain itu peneliti juga menganalisa uji hipotesis yang terdiri dari Uji Koefisien Korelasi, Uji Koefisien Determinasi, Uji Regresi Linear Sederhana, dan Uji T. Hasil hipotesis yang peneliti teliti guna mengetahui besar pengaruh variabel kualitas produk terhadap pemilihan vendor.

Dari hasil uji tersebut peneliti mendapatkan hasil uji hipotesis yang menunjukan bahwa nilai Koefisien Korelasi (R) sebesar 0,664. Nilai tersebut menunjukkan bahwa pengaruh variabel Kualitas Produk terhadap Pemilihan Vendor di PT. Hitachi Power Systems Indonesia adalah kuat.

Sedangkan koefisien determinasi $\left(R^{2}\right)$ menunjukkan nilai $R$ Square $=0,441$ Artinya variabel Kualitas Produk (X) dapat menerangkan atau menjelaskan Pemilihan Vendor (Y) sebesar 44,1\%, sisanya sebesar 55,9\% (dari penghitungan $100 \%-44,1 \%$ ) dipengaruhi oleh variabel lain yang tidak termasuk dalam model atau persamaan pada penelitian ini.

Dalam uji Regresi Linear Sederhana, Nilai a $=6,852$ adalah konstanta. Artinya apabila variabel Kualitas Produk (X) sama dengan nol, maka Pemilihan Vendor (Y) sebesar 6,852. Diketahui besarnya koefisien regresi Kualitas Produk (X) diperoleh 0,833 bernilai positif. Hasil tersebut menunjukkan bahwa setiap terjadi peningkatan Kualitas Produk (X) sebesar satu satuan maka akan diikuti oleh peningkatan Pemilihan Vendor (Y) sebesar 0,833 satuan atau sebaliknya apa bila terjadi penurunan Kualitas Produk (X) sebesar satu satuan maka akan diikuti oleh penurunan Pemilihan Vendor (Y) sebesar 0,833 satuan.

Berdasarkan Uji T menunjukkan variabel Kualitas Produk (X) mempunyai nilai t-Hitung sebesar 5,478. Nilai t-Tabel pada tingkat signifikansi 0,05 yaitu sebesar 1,685. Pada penelitian ini terdapat hipotesis:

$\mathrm{H}_{0}=$ Tidak terdapat pengaruh antara Kualitas Produk terhadap Pemilihan Vendor.

$\mathrm{H}_{1}=$ Terdapat pengaruh antara Kualitas Produk terhadap Pemilihan Vendor.

Hasil analisis menunjukkan nilai t-Hitung > t-Tabel $(5,478>1,685)$. Hal ini berarti $\mathrm{H}_{\mathrm{o}}$ ditolak dan $\mathrm{H}_{1}$ diterima, atau terdapat pengaruh antara Kualitas Produk terhadap Pemilihan Vendor.

\section{KESIMPULAN DAN SARAN}

\section{Kesimpulan}

Berdasarkan hasil penelitian yang telah dilakukan oleh peneliti, maka dapat didapatkan kesimpulan sebagai berikut:

Hasil analisis menunjukkan nilai t-Hitung > t-Tabel $(5,478>1,685)$. Hal ini berarti $\mathrm{H}_{\circ}$ ditolak dan $\mathrm{H}_{1}$ diterima, atau terdapat pengaruh antara Kualitas Produk terhadap Pemilihan Vendor.vKualitas Produk (X) dapat menerangkan atau menjelaskan Pemilihan Vendor (Y) sebesar $44,1 \%$, sisanya sebesar $55,9 \%$ (dari penghitungan $100 \%-44,1 \%$ ) dipengaruhi oleh variabel lain yang tidak termasuk dalam model atau persamaan pada penelitian ini.

\section{Saran}

Berdasarkan hasil penelitian yang peneliti lakukan, maka peneliti mengemukakan saran bahwa dalam mengimplementasikan kualitas produk perlu lebih ditingkatkan dengan cara menekan jumlah cacat produk seminim mungkin namun tetap menjaga kualitas agar tidak cacat atau reject. Hal ini dapat dilakukan dengan melihat historical beberapa waktu lalu sesuai 
kebijakan perusahaan untuk dijadikan perencanaan pengendalian kualitas produk beberapa waktu kedepan.

Selain itu perusahaan juga perlu menentukan jumlah vendor secara lebih tepat untuk menghadapi fluktuasi permintaan yang tidak dapat diperkirakan. Dengan implementasi pengendalian kualitas produk sebaik mungkin baik dengan menekan jumlah cacat produk maupun mengantisipasi kemungkinan reject dengan adanya pemilihan vendor ber-kualitas, maka perusahaan mampu menekan jumlah cost yang seharusnya dikeluarkan oleh perusahaan akibat dari perbaikan cacat produk, kerusakan, waktu perbaikan namun tetap mampu memuaskan konsumen dengan kualitas produk yang baik dan proses produksi tepat waktu. Dan pemilihan vendor merupakan hal terpenting di dalam perusahaan.

\section{REFERENSI}

Bowersox, DJ. 2006. Manajemen Logistik 1. Jakarta : Bumi Aksara.

Alma, Buchari. 2002. Manajemen Pemasaran dan Pemasaran Jasa. Bandung : Alfa Beta.

Kotler, Philip dan Gary Amstrong. 2001. Prinsip - Prinsip Pemasaran. Alih Bahasa oleh Nurmawan, Imam. Jakarta : Erlangga.

Kotler, Philip. 2005. Manajemen Pemasaran 2 Edisi Kesebelas. Alih Bahasa oleh Molan, Benyamin. Jakarta : Indeks.

Lupiyoadi, Rambat. 2001. Pemasaran Jasa. Jakarta : Salemba Empat.

McCarthy dan Perreault. 2003. Dasar-dasar Pemasaran. Alih Bahasa oleh Darma Jakarta : Erlangga.

Tjiptono, Fandy. 2001. Strategi Pemasaran Edisi Kedua. Yogyakarta : Andi.

Basu Swasta dan Hani Handoko. 2010. Manajemen Pemasaran : Analisa dan Perilaku Konsumen.BPFE. Yogyakarta.

Pujawan, I Nyoman dan Mahendrawathi. 2010. Supply Chain Management. Surabaya : Guna Widya.

Sekaran, Uma. 2003. Research Methods For Business 1 Edisi 4. Terjemahan oleh : Kwan Men You.2011. Jakarta : Salemba Empat.

Sugiyono. 2014. Metode Penelitian Pendidikan Pendekatan Kuantitatif, Kualitatif dan $R \& D$.Bandung : Alfa Beta.

Ghozali, Iman. 2009. Aplikasi Analisis Multivariate dengan Program SPSS. Semarang : Badan Penerbit UNDIP.

\section{JURNAL}

Ramanda, GP. 2019. Analisis Pemilihan Supplier Alat Tulis Kantor dengan Metode Analitycal Hierarchy Process pada PT Bank XYZ Kantor Pusat. Jurnal Logistik Indonesia. 3(2) : 111-124.

Prawira, B. 2014. Pengaruh Kualitas Produk, Citra Merk dan Persepsi Harga Terhadap Minat Beli Produk Smartphone Samsung di Kota Denpasar. Jurnal of Basic and Applied Scientific Reseach. 2(4) : 3552 - 3556.

Hermawan, B. 2011. Pengaruh Kualitas Produk, Terhadap Kepuasan, Reputasi Merk dan Loyalitas Konsumen Jamu Tolak Angin PT. Sido Muncul. Jurnal Manajemen Teori dan Terapan. Tahun 4, No. 2, Agustus 2011.

Puspitasari, dkk. 2016. Analisis Pemilihan Supplier Ramah Lingkungan dengan Metode Analytical Network Process (ANP) pada PT. Kimia Farma Plant Semarang. Jurnal Teknik Industri. XI(1), Januari 2016.

Giantoro, A. 2015. Analisis Keputusan Pemilihan Vendor dalam Proyek Kontruksi (Skripsi).

Yogyakarta (ID). Un 